日臨外会誌 $47(6), 754-759,1986$

症例

肝内門脈左枝からの副血行路が供血路となった食道静脈瘤の 2 例

\begin{tabular}{|c|c|c|c|c|c|c|c|c|c|c|c|}
\hline \multicolumn{12}{|c|}{ 大阪市立大学医学部第 1 外科（主任：梅山 馨教授） } \\
\hline 東 & 郷 & 杏 & 一*1 & 金 & & 義 & 哲*2 & 西 & 野 & 裕 & 二*3 \\
\hline$\frac{1}{5}$ & 原 & 雅 & 司*1 & 山 & 本 & 時 & 忠*2 & 永 & 井 & 裕 & 司 $* 4$ \\
\hline 中 & 河 & 宏 & 治*2 & 吉 & 川 & 和 & 彦*3 & 山 & 下 & 隆 & 史*3 \\
\hline & & & 馨*5 & & & & & & & & \\
\hline
\end{tabular}

*1 大阪市立大学医学部第 1 外科教室研修医 *2 同 研究医

*3 同 助手 *4 同 大学院生 $* 5$ 同 教授

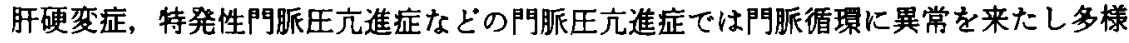
な副血行路が生じる，その中で最も多いのは左胃静脈，短胃静脈，後胃静脈(無名静脈) を介して食道・胃静脈瘤を形成する副血行路である，肝内門脈枝よりの副血行路として は, 肝内門脈䐗部より脐静脈を介し浅腹壁静脈が执張驼行を示す Cruveilhier-Baumgarten 症候群がく知られている。しかし, 肝内門脈枝より直接食道・胃静脈瘤へ行く副血 行路の報告は亟めて少ない。当教室において1979年 2 月から1985年 8 月までの, PTP 施 行例中，食道・胃静脈瘤への副血行路を同定できた 36 例を検討すると，2例に肝内門脈 枝が食道・胃静脈瘤の副血行路に関与していることを証明しえた。これまでに報告され ている肝内門脈枝より食道・胃静脈瘤への短絡例は自䋡例を含めて20例にすぎず，比較 的稀と思われるので報告した。

来引用語：門脈王元進症，食道・胃静脈瘤，释皮释肝的門脈造影

\section{緒 言}

肝硬变症および特発性門脈圧六進症などの門脈圧立 進症では門脈循環に異常をきたし種々の副血行路が生 しるが，最す多いのは，左胃静脈，短胃静脈，また後 胃静脈（いわゆる無名静脈）などが供血路となり胃上 部・下部食道にて静脈瘤を形成する副血行路である.

しかし肝内門脈枝が供血路となり食道・胃静脈瘤を 形成するといら報告は極めて少ない，今回, 術前の経 皮释肝的門脈造影(以下PTP と略す)により肝内門脈 枝からの副血行路が関与することを確認しえた食道・ 胃静脈瘤の 2 症例を経験したので, 若干の文献的考察 を加えて報告する。

$$
\text { 症 例 } 1
$$

患者：49歳，男性.

主訴：吐下血.

家族歴：父親が74歳時に再生不良性費血にて死亡。

既往歴：7藏時に猩紅熱，46歳時に慢性肝炎に罹患
†.

現病歷：昭和58年 8 月，11月に下血出現，某医受診 し, 肝硬变症批上び食道静脈瘤の診断のもとに保存的 治療をらけるも，昭和59年 6 月 6 日吐下血が出現し， 同年 7 月 11 日当科に入院となる。

入院時現症：身長 $165 \mathrm{~cm}$ ，体重 $60 \mathrm{~kg}$ ，眼瞼結膜に軽 度年血を認めるも，眼球結膜に黄疸は認めなかった。 胸部では心音，呼吸音ともに異常なく，腹部では肝は 右鎖骨中線上で 3 横指，心窝部で 2 横指触知するす， 軒は触知せず，腹水や腹壁静脈の怒張も認められな かった。

入院時梌查成綨: 末梢血では赤血球数273万/ $\mathrm{mm}^{3}$, へモグロビン $8.8 \mathrm{~g} / \mathrm{dl}$ と中等度の負血を認め,生 化学検查では総蛋白 $6.8 \mathrm{~g} / \mathrm{dl}$, アルブミン $3.3 \mathrm{~g} / \mathrm{dl}$, 千 モール $4.4 \mathrm{u}$, クンケル $17.6 \mathrm{u}$, コリンメステラーせ0.24 $\Delta \mathrm{pH}, \mathrm{ICG} 15$ 分停滞率 $24.5 \%$ と肝硬变様パターンを示 していた（表1）.

上部消化管造影：中部食道より下部食道にかけ連珠 状の静脈瘤を認めた（図 1 左）。 
表 1 入院時検查成增

\begin{tabular}{|c|c|c|c|}
\hline 项 & 目 & 是例 1 & 姃例 2 \\
\hline \multicolumn{4}{|l|}{ 血㴗提查 } \\
\hline wBC & $\left(/ m m^{3}\right)$ & 6700 & 2200 \\
\hline RBC & $\left(10 \% / \mathrm{mm}^{3}\right)$ & 273 & 363 \\
\hline $\mathrm{Ht}$ & $(\%)$ & 25.4 & 32.7 \\
\hline $\mathrm{Hb}$ & $(g / d t)$ & 8.8 & 11.5 \\
\hline Platelet & $\left(10^{4} / \mathrm{mm}^{3}\right)$ & 13.2 & 4.9 \\
\hline Prothrombin $t$ & (sec.) & 12.6 & 11.3 \\
\hline Hepaplastin $\mathrm{t}$. & (\%) & 63 & 77 \\
\hline \multicolumn{4}{|l|}{ 生化﨔的栋查 } \\
\hline T.P. & $(\mathfrak{g} / \mathrm{d} t)$ & 6.8 & 6.4 \\
\hline albumin & $(\mathfrak{g} / \mathrm{d} \boldsymbol{t})$ & 3.3 & 4.1 \\
\hline$\gamma \cdot$-globulin & $(\%)$ & 23.2 & 17.3 \\
\hline GOT & (UU) & 60 & 25 \\
\hline GPT & (IU) & 43 & 25 \\
\hline T-Bit & $(\mathrm{mg} / \mathrm{d} \ell)$ & 0.7 & 0.9 \\
\hline TTT & (IU) & 4.4 & 1.1 \\
\hline ZTT & (IU) & 17.6 & 10.7 \\
\hline Al-P & (KAU) & 8.4 & 5.1 \\
\hline CHE & $(\Delta \mathrm{pH})$ & 0.24 & 0.31 \\
\hline$\gamma$-GTP & (mu/ml) & 24 & 10 \\
\hline LDH & (wu) & 398 & 183 \\
\hline$I C G_{15}$ & (\%) & 24.5 & 15.5 \\
\hline \multicolumn{4}{|l|}{ *の 他 } \\
\hline HBs 抗原 & & 隆性 & 胜 \\
\hline a-fetoprotein & $(n g / m l)$ & 18.3 & 7.9 \\
\hline CEA & $(\mathrm{ng} / \mathrm{m} l)$ & 1.2 & 0.8 \\
\hline
\end{tabular}

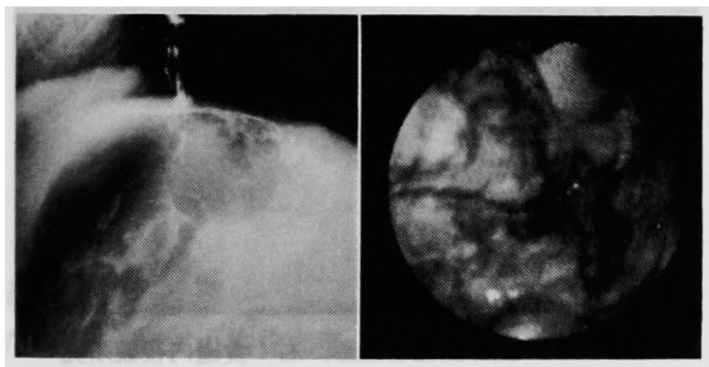

国 1 左：上部消化管造影．右：食道内視鏡所見

食道・胃内視鏡検查所見：食道中部より下部にかけ て白色調の連珠状から結節状に隆起した静脈瘤を認 め, R-Csign は陽性であった（図1右)。

腹部超音波検查所見：肝臟は表面不整，辺縁鈍，内 部エコーは不均一で肝硬变様を呈していたが占拠性病 変は認められなかった。脾䁍は中等度腫大していた。 また腹水も中等量存在していた。

PTP およU塞栓術所見：脾門部脾静脈造影では門 脈本幹は直径約 $20 \mathrm{~mm}$ に抬張しており短胃静脈及び無 名静脈を主とし，一部左胃静脈を供血路とする食道静 脈瘤を認めた。肝内門脈枝の静脈嘴への短絡の有無は 明瞭でなかった。門脈本幹王は $380 \mathrm{mmH}_{2} \mathrm{O}$ であった
（図 2 ）。選択的に短胃静脈，無名静脈を造影したとこ ろいずれる静脈瘤への短絡を認めた（図 3).短胃静脈， 無名静脈を $99 \%$ ×タール，スチールコイルにて塞栓 術を施行した．塞栓後の脾門部脾静脈造影では前記の 血管よりの静脈瘤への供血路は遮断できたが，門脈左 外側下行枝を供血路とした食道静脈瘤が造影された （図 4).

入院後下血が止まらず昭和59年 8 月 6 日に緊急手術 を施行した。

手術時所見：上腹部正中切開にて開腹すると, 腹水 は存在せず，肝䏩は右葉が萎縮し，左葉には代償性肥 大がみられ，またその表面には小結節が多数存在し明 らかに肝硬変像を呈していた。門脈正は300 $\mathrm{mmH}_{2} \mathrm{O}$ で，脾䁍は軽度に腫大していた，肝左葉外側下面より 小網を経由し食道静脈瘤へ短絡する副血行路を確認し

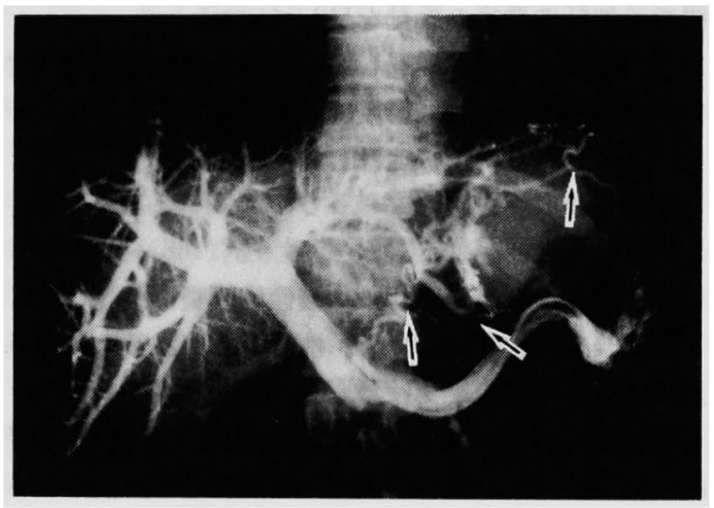

图 2 脾門部脾静脈造影：矢印の如く短胃静脈，無名 静脈，左胃静脈より食道静脈瘤への短絡を認めた。 肝内門脈枝の静脈瘤への短絡の有無は明瞭でなかっ た.

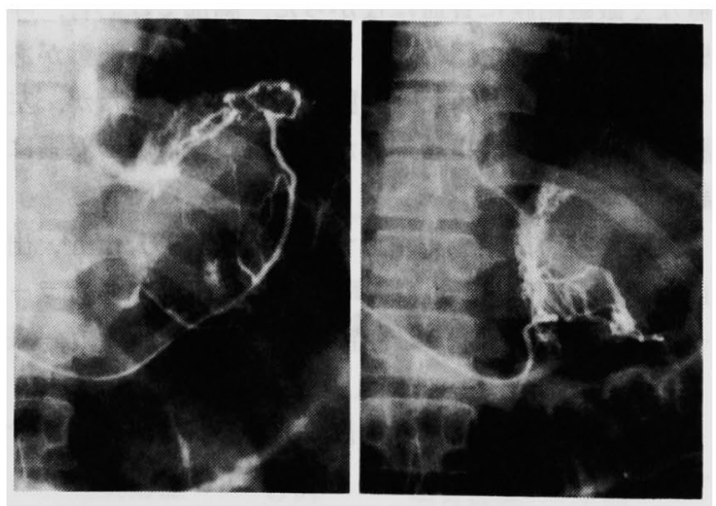

图 3 左：選択的短胃静脈造影。右：選択的無名静脈 造影 


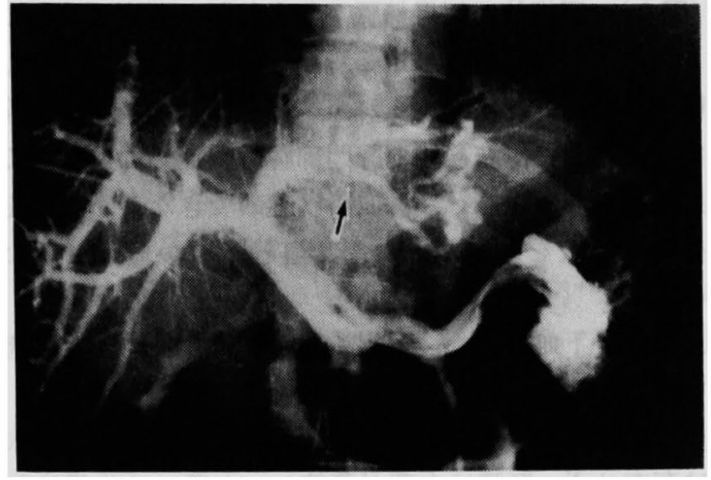

図 4 塞栓後の脾門部脾静脈造影 : 矢印の如く門脈左 外側下行枝より静脈瘤への短絡を認めた。

た。血管郭清, 胃上部切除術, 脾摘術; 幽門形成術を 行って手術を終えた．摘出脾重量は285gであった。

病理組織学的所見：肝霹は大小の偽小葉の形成が著 明で乙型肝硬变症の所見を呈していた。

術後経過：順調に経過し 1 力月後の内視鏡検査にて 食道静脈瘤も消失し, 術後66日目に軽快退院した。 症 例 2

患者：46歳, 女性.

主訴：全身倦急感。

家族歴：母親が35歳時に化膿性檤膜炎にて死亡.

既往歷：19歳時アルコール性肝障害，28歳時に虫垂 炎にて虫垂切除原を受けた。

現病歴：昭和59年 9 月頃全身供急感出現し某医受 訅, 肝機能異常, 脾庫, 食道・胃静脈瘤を指摘される も，特に症状なく経過していたが，昭和60年 1 月27日 及び28日に吐血が出現し，手術目的のため当科へ入院 となった。

入院時現症：身長 $150 \mathrm{~cm}$, 体重 $46 \mathrm{~kg}$ ，眼球結膜に黄 疸なく眼瞼結膜に筫血はなかった，胸部では心音，呼 吸音ともに異常を認めなかったが，腹部では波動があ り腹水の存在を認めた。肝臟は触知しなかったが，左 助弓下に脾を 4 横指触知した。なお腹壁静脈の怒張は 認めなかった。

入院時検查成績: 末梢血で血小板数 4.9 万 $/ \mathrm{mm}^{3}$, 出 血時間 6 分, ICG15分停滞率15.5\%, コリンエステラー ゼ0.31 $\mathrm{pHH}$ を呈する以外特に異常を認めなかった（表 1).

上部消化管造影所見：中部食道から胃穹隆部にかけ て連珠状の静脈瘤を認めた（図 5 左）。

食道・胃内視鏡検查所見：中部食道より胃害隆部に かけて白色調の連殊状〜結節状の静脈瘤を認め, R-
Csignは陽性であるがびらん等はなかった(図 5 右). 腹部超音波検查所見：肝臓は左葉が萎縮して打り右

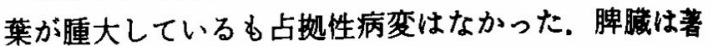
明に腫大しており門脈の抎張著明であるが副血行路は 明瞭でなかった。

PTP 及ひ塞栓術所見：脾門部脾静脈造影では肝内 門脈左外側上行枝が主たる供血路となった食道・胃静 脈瘤を認めた。短胃静脈及び左胃静脈の扗張は著明て なく，門脈は $340 \mathrm{mmH}_{2} \mathrm{O}$ であった（图 6)，選択的 造影にて左外側上行枝より食道・胃静脈瘤が明膫に描 出された(図 7). 左外側上行枝をスチールコイルにて 塞栓術を施行した。塞栓後の脾門部脾静脈造影では塞 栓部は遮断されており静脈瘤は描出されなかった（図 8 ).

手術時所見：上腹部鉤状切開にて開腹すると, 肝左 葉は睡大脾により王排されて萎縮して打り肉眼的には 肝硬変様であったが，右葉は表面には明らかな結節は 見られず肝線維症の外観を呈していた。 また肝左葉外 側下面に術前 PTP で確認されていた門脈左外側上行 枝から胃小弯側小網を経由し噴門に至る静脈が磼認さ

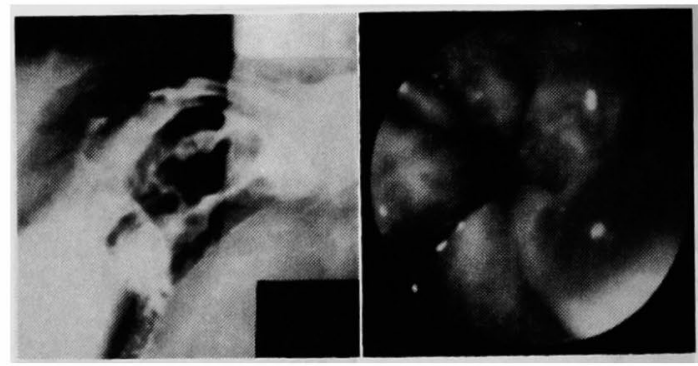

図 5 左：上部消化管造影．右：食道内視鏡所見

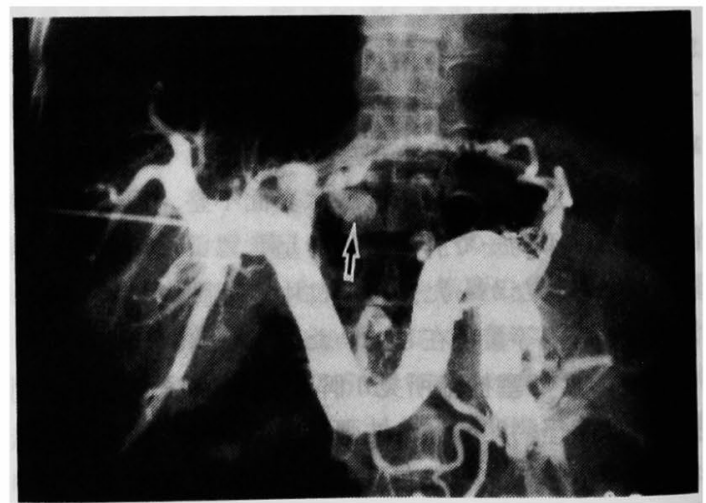

图 6 膰門部胖静脈造影 : 矢印の如く門脈左外側上行 枝より静脈嵧への短絡を認めた。 


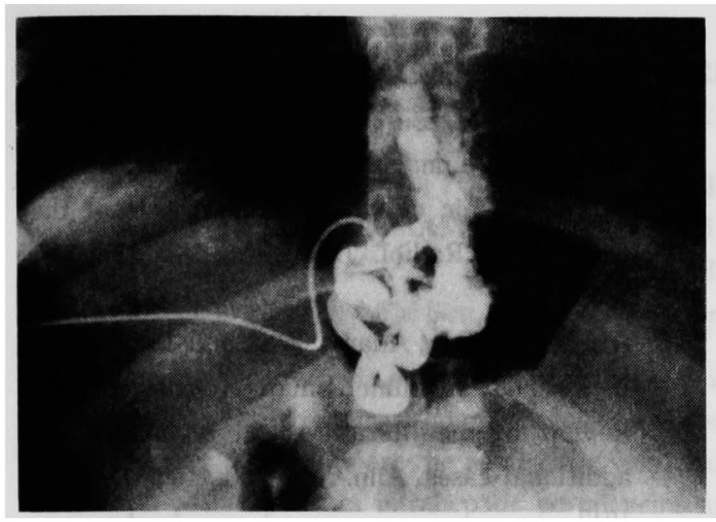

图 7 選択的肝内門脈枝造影：門脈左外側上行枝より 觧脈面への短絡を認めた。

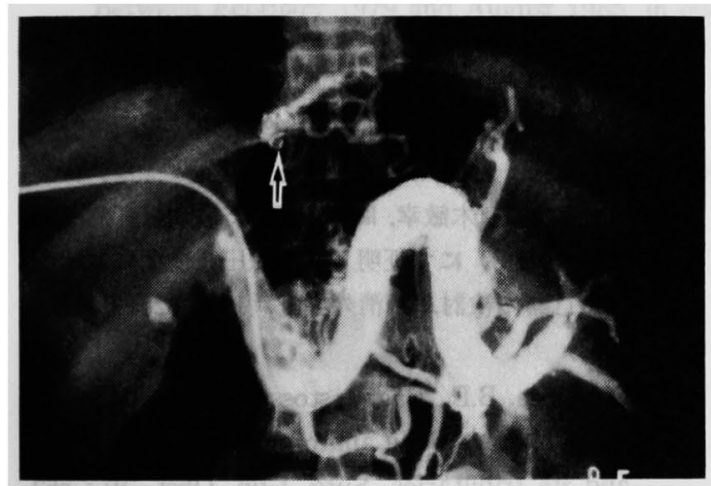

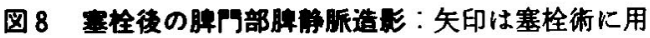
いたスチールコイルである．肝内門脈枝より静脈瘤 への短絡は認められなかった。

れた，同血管は血栓化しており塞栓術が効果的であっ たことを認めた。血管郭清, 脾摘術, 幽門形成術を行っ た.

病理組轼学的所見：肝右葉の生検組織像は硬変像は 見られず，線維化の像が認められた。

術後経週：順調に経過し術後45日目に軽快退院と なった。

\section{考察}

門脈圧六進症時の副血行路については数多く報告さ れてきている12).そのなかで最も多いのは左胃静脈, 後胃静脈 (無名静脈), 短胃静脈を介して食道・胃静脈 虜を形成する副血行路である，稀ではあるが肝内門脈 枝よりの副血行路としては，肝内門脈脐部より脐静脈 を介し浅腹壁静脈が搪張驼行を示すCruveilhier Baumgarten 症候群 ${ }^{3}$ (以下 C-B 症候群と略す)がこれ までに報告されている。
しかし䀒内門脈枝上り直接に食道静脈瘤へと行く副 血行路の報告は本邦においてはこれまでに三富ら”,

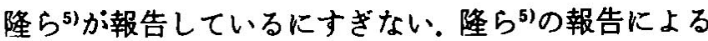
と，83例の PTP 施行例中わずか 1 例 $(1.2 \%)$ にのみ 旰内門脈枝より直接食道静脈瘤への短絡が認められた にすぎない。

副血行路に関する三好ら6)の報告においてる肝内門 脈枝上りの副血行路は前迈の C-B 症候群之傍㜔静脈 から上腹壁静脈，内胸静脈を経由し鎖骨下静脈へとい く遠肝性の上行性副血行路のみであった。

当教室において1979年 2 月から1985年 8 月までに, 塞栓術, 硬化療法, 手術等を行っていない症例で PTP 施行し，食道・胃静脈瘤への副血行路が明らかに同定 し得た 36 症例を検討すると,左胃静脈が20例( $55.6 \%)$, 左胃静脈之無名静脈が 5 例(13.9\%)，左胃静脈と無名 静脈と短胃静脈か 4 例 (11.1\%)，短胃静脈方 2 例 (5.6\%), 無名静脈かi 2 例 $(5.6 \%)$, 左胃静脈之短胃静 脈と右胃静脈が 1 例 $(2.8 \%)$, 左胃静脈と無名静脈と 短胃静脈之肝内門脈枝が 1 例 $(2.8 \%)$, 訮内門脈枝が 1 例（2.8\%）であった（表 2）。また食道・胃静脈瘤 の供血路として関与する各静脈別の頻度は左胃静脈が 36 例中 31 例(86.1\%)，無名静脈が36例中12例(33.3\%), 短胃静脈が36例中 8 例 $(22.2 \%)$, 肝内門脈枝か3 36 例中 2 例 $(5.6 \%)$ ，右胃静脈が36例中 1 例 (2.8\%) であっ た（表 3)。このように左胃静脈が多数を占め，その他 無名静脈，短胃静脈が関与することはこれまでの諸家 の報告と同様であるが，稀な肝内門脈枝からの副血行

\section{表 2 食道胃静脈痛への供血路（PTP 施行例）}

\begin{tabular}{|c|c|c|}
\hline 1) & 左国睁哌 & 20 例 \\
\hline 2) & 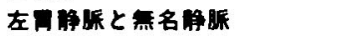 & 5 例 \\
\hline 3) & 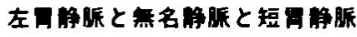 & 4 例 \\
\hline 4) & 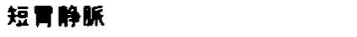 & 2 例 \\
\hline 5) & 监名解助 & 2 侧 \\
\hline 6) & 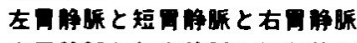 & 1 例 \\
\hline 7) & 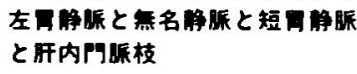 & 1 例 \\
\hline 8) & 肝内門趣枝 & 1 则 \\
\hline
\end{tabular}

表 3 食道胃静脈瘦36例の静脈瘦への供血路として関 与する各静脈別の頻度

\begin{tabular}{|c|c|c|c|}
\hline 左用觧眽 & 31 例 & 每名艓眽 & 12 例 \\
\hline 短月舴娦 & 8 例 & 右胃觧胝 & 1 例 \\
\hline 肝内門脈枝 & 2 例 & & \\
\hline
\end{tabular}


路の存在がみられた。鶴丸”の報告しているよらな後 腹膜の静脈や下横隔膜静脈が食道・胃静脈瘤に短絡し ている症例はみられなかった。

自験 2 症例（1 例は肝硬变症，1例は特発性門脈圧 六進症）は肝内門脈枝からの副血行路により食道・胃 静脈瘤を形成すると言ら点で極めて稀である。我々の 症例において肝内門脈枝を経由するす C-B 症候群と 異なり食道・胃静脈瘤を形成する遠肝性の上行性副血 行路が明らかになった。しかし問題となるのは，左胃 静脈が訮内門脈枝に合流していてあたかも肝内門脈枝 より食道・胃静脈瘤を形成するかのように見えること である. Douglass ら》は92例の剖検例において左胃静 脈を検索し，そのうち90例で左胃静脈を同定しえたと ころ, 左胃静脈の合流部位は, 脾静脈が $16.7 \%(15 / 90)$, 脾静脈と上腸間膜静脈の合流部が $58.9 \%(53 / 90)$, 門 脈本幹が24.4\%（22/90）であった。しかし Douglass らクは 2 例において左胃静脈の同定はでず，その 2 例 は左胃静脈が肝内門脈枝に合流している可能性を述へ ている。すしこのよらな variationをもっている場合 において門脈圧立進症が生じれば，肝内門脈枝より直 接食道・胃静脈瘤へと副血行路が生じる可能性は十分 にあり5ることである。しかし我々の 2 症例はいずれ す左胃静脈が存在していたので, Douglass らの述べる よらな variation ではなく，門脈圧六進によって生じ た新たな副血行路である可能性が考兄られる。欧米に おいては我々と同様の副血行路の存在を Reichardt

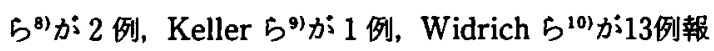
告しており，文献的検索によると自験例を含めて20例 にすぎない。

これまでに述べたよらに門脈圧六進症例では様々の 副血行路が存在するので術前のPTP は副血行路の確 認及び手術時の血管郭清の目安のため,さらに門脈循 環動態を知る上で不可欠な検查であると思われた。

結語

今回我々は肝内門脈枝からの副血行路が関与する食 道静脈瘤の 2 症例を経験したので若干の文献的考察を 加えて報告した。

\section{文䰚}

1) 鶴丸昌彦: 門脈圧六進症における遠肝性副血行路 の検討, 日外会誌, 80：424-441，1979.

2) Hoevels, J., Lunderquist, A., Tylen, U., et al. : Proto-systemic collaterals in cirrhosis of the liver. Acta Radiol. Diangosis, 20: 865-877, 1979.

3) Armstrong, E.L., Adams, W.L. and Tragerman, L.J.: The cruveilhier-Baumgarten syndrome: Review of the literature and report of two additional cases. Ann. Int. Med., 16: 113-151, 1942.

4）三富利夫，野登 隆，田中 豊：門脈圧元進症の病 態理解に必要な臨床解剖。消外セミナー,井口 著者代表, $18: 15-38 ， 1985$.

5）隆 元英，高安是一，高円博文他：経皮経肝的門脈 造影法について(第 6 報)門脈圧方進症における肝 外門脈短絡路とその臨床的意義, 肝葴, 21 ： $857-865,1980$.

6）三好敦生，植木敏幸, 間野正筆他 : 経皮経肝的門脈 造影（PTP）にて証明した門脈圧六進症における 副血行路の検討, 日消外会誌， $16: 1328-1333$, 1983.

7) Douglass, B.E., Baggenstoss, A.H. and Hollinshead, W.H.: The anatomy of the portal vein and its tributaries. Surg. Gyn. Obst., $91: 562$ $-576,1950$.

8) Reichardt, W., Bützow, G.H. and Erbe, W.: A. nomalous venous connections involving portal system. Cardiovasc. Radiol., 2 : 41-46, 1979.

9) Keller, F.S., Dotter, C.T. and Rösch, J.: Percutaneous transhepatic obliteration of gastroesophageal varices: Some technical aspects. Radiol., 129 : 327-332, 1978.

10) Widrich, W.C., Srinivasan, M., Semine, M.C., et al.: Collateral pathways of the left gastric vein in portal hypertension. A.J.R., $142: 375$ $-382,1984$. 


\title{
TWO CASES OF ESOPHAGEAL VARICES WITH THE COLLATERAL PATHWAY OF THE LEFT INTRAHEPATIC PORTAL BRANCH TO THE VARICES
}

\author{
Kyouichi TOGO, Euichol KIM, Hiroji NISHINO, Masashi TOYOHARA, \\ Tokitada YAMAMOTO, Hiroji NAGAI, Koji NAKAGAWA, Kazuhiko YOSHIKAWA, \\ Takahumi YAMASHITA and Kaoru UMEYAMA \\ The First Department of Surgery, Osaka City University Medical School
}

In portal hypertension, such as liver cirrhosis or idiopathic portal hypertension, there are various collateral circulations due to extraodinary portal circulation. In such cases, the most probable collateral pathways related to gastroesophageal varices are the left gastric vein, short gastric vein and posterior gastric vein. On the other hand, collateral pathways from intrahepatic portal veins are well known as Cruveilhier-Baumgarten syndrome, which presents dilated and tortous superficial abdominal wall veins communicating with the umbilical vein deriving from the umbilical point of the intrahepatic portal vein.

But reports of so abnormal pathway from the intrahepatic portal vein to gastroesophageal varices are rare.

Between February 1979 and August 1985, in our department, we studied 36 patients in whom the collateral pathways to gastroesophageal varices were identified by percutaneous tranahepatic portography. In two cases, the direct pathway to the gastroesophageal varices from the intrahepatic portal vein was proved. Only 20 such cases, including our two, have been reported.

Thus, we present these two cases in addition to a review of the literarure. 